\title{
Teaching for Civil Society in Finland: A Canadian Perspective on Finnish Educators' Reflections
}

\author{
Paul Orlowski \\ University of Saskatchewan
}

Author's Note

This study was funded by a John Ranton McIntosh grant.

\begin{abstract}
This article describes a study that took place in Helsinki, Finland in late 2015. A Canadian education professor conducted individual interviews with Finnish educators: six practicing teachers in Helsinki schools, two education professors at the University of Helsinki, and the advisor to the president of Finland's teachers' union. Although all five Nordic countries are known to support the social welfare state, Finland was chosen because it is considered to be the most economically left. The study is an exploration of how Finnish educators consider their role and the role of the school regarding civil society and the commons in Finland. The actual research question for the study was, "How do Finnish educators think about the school's role in supporting the commons and in fostering social cohesion with immigration?" The nine participants were unanimous in their support of the commons and Finland's generous social welfare state, apparently the result of a collectivist mentality in Finnish society. However, there appears to be growing social, economic, and political discrimination for immigrants and refugees who look different from White Finns. The six teacher-participants expressed uncertainty around how best to deal with these tensions, and were committed to attempting neutrality in their teaching of these social problems, or perhaps even ignoring them altogether. Despite the small sample set, I believe it represents a cross section of views of educators in contemporary Finland. Recent studies mentioned in the literature review support this position. Some comparisons with similar studies in Canada are briefly mentioned.
\end{abstract}

Keywords: teaching for social justice; comparative education; Finnish education; controversial issues; Nordic social democracy 


\section{Teaching for Civil Society in Finland: A Canadian Perspective on Finnish Educators' Reflections}

From the nineteenth century onwards, [Finnish] civic movements and the state have been working towards common aims ... Perhaps this is the basic reason why the welfare state is still seen as the legitimate representative of society and of the common good. (Simola, 2015, p. 73)

For a variety of reasons, Finland's school system has garnered a great deal of attention among educators in international circles. Much of this has to do with the country's repeated high rankings in the test scores of the Program for International Assessment (PISA) administered by the Organisation for Economic Co-operation and Development (OECD) every three years. Beginning with the release of the first set of PISA exam scores in 2001, Finland's international reputation began to shine brightly-Finnish 15-year-olds were collectively at, or near, the top in all three tested subject areas-mathematics, reading, and science literacy (Andere, 2015; Hargreaves \& Shirley, 2011; Sahlberg, 2014; Simola, 2015). ${ }^{1}$ Finland's stellar performances on the PISA exams, however, were not the reason for the study I conducted with Finnish educators in the late summer of 2015.

As a life-long social democrat and progressive educator in Western Canada for over 30 years, I have developed an admiration for the Nordic Way, a sociopolitical vision based on Keynesian economics that influences government policy in Sweden, Denmark, Norway, Iceland, and especially Finland (Partanen, 2016; Simola, Carlgren, Klette, Myrdal, \& Schnack, 2015). After a brief flirtation with neoliberalism during a national recession in the early 1990s, the Finnish government reverted back to the Finnish version of Keynesian economics, one that is overtly committed to equality, especially as it pertains to opportunity and access to a comfortable material life (Simola, 2015). There are recent signs, however, that the Finnish people are beginning to notice a weakening commitment to the welfare state, giving rise to an antiimmigrant movement (Burtenshaw, 2017).

I was compelled to study why Finland, arguably the most economically left of the five Nordic nations, has for the most part been able to veer away from adopting neoliberalism, more so than other Western nations. Finland uses progressive taxation to support a strong social welfare state, one that includes a well-funded public healthcare system, free dental work for all Finns up until the age of 18, free tuition for post-secondary education, free school lunches for all students, and of course, their world renowned public school system. Scholars (Hargreaves \& Shirley, 2011; Sahlberg, 2014) have written about the Finnish government eschewing the neoliberal Global Education Reform Movement (GERM). The major focus of the study described in this article, and its main contribution to the scholarly literature on Finland's school system, is to explore how Finnish educators consider their role and the role of the school in general in maintaining or even strengthening civil society and the commons in Finland. Before the details of this study are discussed, however, it is prudent to briefly mention related findings in the scholarly literature.

\section{The Literature on the Role of Finland's Teachers Within Finnish Civil Society}

Until very recently, most academic literature produced in Finland was only available in Finnish. This has changed over the past two decades with much more published in English, mainly because of Finland's success on the PISA exams. That said, it is still the case that there is very 
little Finnish research being done on its own school system (Sahlberg, 2014), and that which pertains to teaching about social class, the commons, and immigration is almost non-existent.

Some Finnish scholars have examined the role of teachers in student achievement (Andere, 2015; Sahlberg, 2006; Simola, 2005). A recent study about educating for democracy in England and Finland found that in schools in both countries citizenship education is being increasingly replaced by neoliberal initiatives such as economic growth and productivity (Raiker $\&$ Rautiainen, 2016). This finding was corroborated by another 2015 study that found the Finnish commitment to equality in schools is being threatened by economically privileged White parents demanding special programs for their children within the comprehensive (i.e., public) schools (Reay, 2016). Indeed, another recent study concluded that growing polarization in Finnish urban areas has led to greater school program ability-based segregation that in turn has resulted in increasing social class and cultural educational attainment gaps (Bernelius \& Vaattovaara, 2016). It is noteworthy that all of these studies took place in 2015, around the same time as when the study described in this article took place.

There is also a dearth of educational research pertaining to immigrants in Finland. The first was published by the OECD in a series called Equity in Education that focused on Finland (Grubb, Jahr, Neumülle, \& Field, 2005). The authors of this report acknowledged that "immigrant issues do not just take care of themselves; they require coherent policies, preferably in place before new waves of immigrants take place" (p. 44). The authors expressed some concern because Finland supports each municipality making decisions around educational policy including language education, rather than central government control. With increased immigration, the authors worried that variation in approaches across municipalities would weaken the Finnish commitment to educational equity. One study from the same time period found that there were challenges and generational tensions within large immigrant Somali families living in Finland because of the different values found in the home and the host country (Degni, Pöntinen, \& Mölsä, 2006). My study explores the thinking of Finnish educators around students of Somali and other cultural backgrounds a decade after these publications.

Very little educational research has been published that examines the role of teachers and the school itself in maintaining Finnish civil society, the commons, and immigration. The Finnish scholarship that provided the groundwork for this study came from two scholars based at the University of Helsinki, Pasi Sahlberg $(2006,2014)$ and Hanu Simola $(2005,2015)$. In Canada and the United States, awareness of Finland's much lauded school system, including its teachers, has come from the work of Pasi Sahlberg, especially from his renowned book, Finnish Lessons 2.0: What can the World Learn From Educational Change in Finland? More than any other Finnish scholar, Sahlberg is considered the most effective ambassador for Finland's school system in the international arena. Within Finland itself, the scholarship of Hanu Simola is highly respected and particularly germane to the study described here. The work of Sahlberg and especially Simola will be referred to throughout.

\section{Setting the Context}

The 1990s recession ... changed the political atmosphere in favour of market liberalism back to traditional Nordic values. The deep economic recession made the value of the safety nets visible even to the middle classes. (Simola, Varjo, \& Rinne, 2015, p. 243) 
The five Nordic countries are known to support the social welfare state according to the socioeconomics of the Nordic Way. Sometimes referred to as the Nordic model or Nordic social democracy, the Nordic Way was the preferred term of the participants in this study. Based on principles of Keynesian economics, citizens in these countries have more or less arrived at some sort of consensus that the best way to alleviate poverty is to provide the populace with employment that pays more than a living wage, strong public healthcare and education systems, and generous pension plans (Partanen, 2016). Finland, perhaps more than the other Nordic countries, is particularly committed to a strong commons because of a variety of factors including its proximity to the Soviet Union, its late transition from an agrarian nation to an industrial one, its long tradition of social democracy, and the collective experience of a frightening recession in the early 1990s (Simola, 2015).

The main focus of this study was to explore the role of the teacher and the public school system in support of the commons, in strengthening civil society, and in fostering social cohesion. I had conducted two studies with Canadian teachers that had a similar focus: first, with 10 department head teachers of social studies in Vancouver high schools (Orlowski, 2011); and second, with 10 social studies teachers who self-identified as Christian in Saskatchewan high schools (Orlowski, 2017). In this particular study, I wanted to discern how Finnish teachers see their role in relation to supporting civil society. The actual research question for the study was, "How do Finnish educators think about the school's role in supporting the commons and in fostering social cohesion with immigration?"

As the title suggests, the analysis of this study relies heavily on quotes from the interview transcripts. The findings of the data analysis will focus on the role of the school and teaching in support of the commons and social cohesion. Despite the small sample size, the conclusions will be relevant for Canadian educators interested in the research question. Some analysis of the studies I have conducted with teachers in the two countries will appear in the final reflections section at the end of the article. It is not, however, a comparison of the perspectives of the Canadian teachers in the two previous studies mentioned above. It is worth noting some words of caution with any comparative approach.

Hannu Simola (2015), a distinguished professor of the history and sociology of education at the University of Helsinki (and one of the nine participants), contends that comparative studies across different countries are inherently flawed mainly because of a lack of theorization. In particular, Simola and his colleagues point to the current tendency in international education to offer a "descriptive collection of educational issues from different countries" (Simola, Varjo, \& Rinne, 2015, p. 224). They contend that international comparisons are limited because global trends collide with "the embedded policies to be found in local spaces" (p. 224). I agree with this assertion, of course, as Finland and Canada have different histories, different demographics, and experience different geopolitics. In short, the two contexts massively differ. That said, I believe that interesting insights can be gleaned from exploring the thoughts of teachers in Finland on important issues involving social cohesion. After all, every nation should consider how best to maintain social cohesion. The main goal of this study, then, is to explore how a group of nine Finnish educators ponder this notion. Of course, with a sample set this small, one must take the findings with a grain of salt. However, most of the findings fit with previous scholarship in Finland on these issues, as rare as that is. 


\section{Recruiting and Interviewing Finnish Educators to Participate}

I used my connections from past trips to Finland in 2013 and 2014 to recruit nine educators: six teachers, two education professors at the University of Helsinki, and the advisor to the president of the teachers union (see Table 1). ${ }^{2}$ I had met one of the two education professors and the advisor to the teacher union president in previous trips to Finland, and they helped me recruit the other participants. One of the education professors, Jorma (his pseudonym), had presented to a group of Canadian teachers I had brought to Helsinki on a Study Abroad tour in 2014 (see Orlowski, 2016). He recruited his colleague at the University of Helsinki, Hannu Simola, to participate. Simola's 2015 book called The Finnish Education Mystery, provided much of the background for this study. (When referring to his interview transcript, I will use only his first name, Hannu, in keeping with how I reference the other participants. When referring to his book, I will use his surname Simola.)

Ritva Semi has been in education since 1977, first as an early childhood educator before she became an advisor to the president of the teachers union (OAJ) in 1999. Semi described her role as one of political influence with the government on education issues and as an advocate for teachers in Finland. The six teacher-participants taught in schools in the greater Helsinki metropolitan area, and had varying experiences as educators: three were primarily elementary school teachers, and three were secondary teachers in different subject areas. (Ritva Semi helped me recruit these six teachers.) Of the nine participants, six were female. Eight of the nine participants were veteran educators, with careers ranging from 12 to 37 years. One participant had only taught for one year and brought a unique perspective to the study, having very recently graduated from her teacher education program. (Note: I am using pseudonyms for seven of the nine participants. The two exceptions are Hannu Simola and Ritva Semi, who asked to have their real first names used when I refer to their interview transcripts.)

Table 1

Participating Finnish Educators

\begin{tabular}{|c|c|c|c|c|}
\hline Name & Gender & $\begin{array}{l}\text { Years as } \\
\text { Educator }\end{array}$ & $\begin{array}{l}\text { Education Positions } \\
\text { Throughout Career }\end{array}$ & Current Position \\
\hline Dorotea & $\mathrm{F}$ & 16 & $\begin{array}{l}\text { Grades 3-9, Language Arts \& } \\
\text { Religion }\end{array}$ & Gr. 6 teacher \\
\hline Ronja & $\mathrm{F}$ & 1 & Grade 4, all subjects & Grade 4 teacher \\
\hline Nils & $\mathrm{M}$ & 12 & $\begin{array}{l}\text { Upper secondary history and } \\
\text { social studies \& vice-principal }\end{array}$ & $\begin{array}{l}\text { Upper secondary social } \\
\text { science teacher \& vice- } \\
\text { principal }\end{array}$ \\
\hline Tova & $\mathrm{F}$ & 14 & Secondary science & $\begin{array}{l}\text { Secondary Physics and } \\
\text { Chemistry teacher }\end{array}$ \\
\hline Birgit & $\mathrm{F}$ & 15 & $\begin{array}{l}\text { Comprehensive (Grades } 1 \text { to } \\
\text { 9); all subjects }\end{array}$ & Grade 6 teacher \\
\hline Tuovi & $\mathrm{F}$ & 31 & Secondary Language Arts & $\begin{array}{l}\text { Secondary Language Arts } \\
\text { teacher }\end{array}$ \\
\hline
\end{tabular}




\begin{tabular}{|l|c|c|l|l|}
\hline Jorma & M & 23 & $\begin{array}{l}\text { 3 years secondary teacher; 12 } \\
\text { years university researcher; } 8 \\
\text { years education professor }\end{array}$ & $\begin{array}{l}\text { Education professor } \\
\text { (University of Helsinki) }\end{array}$ \\
\hline Hannu & M & 30 & $\begin{array}{l}\text { 10 years secondary grades } \\
\text { (Ethics); 20 years as education } \\
\text { professor }\end{array}$ & $\begin{array}{l}\text { Education professor } \\
\text { (University of Helsinki) }\end{array}$ \\
\hline Ritva & F & 37 & $\begin{array}{l}7 \text { years as early childhood } \\
\text { educator; 30 years on OAJ } \\
\text { executive; (the last 16 years as } \\
\text { special advisor to the OAJ } \\
\text { President) }\end{array}$ & $\begin{array}{l}\text { Special Advisor to the OAJ } \\
\text { President }\end{array}$ \\
\hline
\end{tabular}

In August 2015, I conducted one-on-one interviews with the nine participants in Helsinki. Each interview lasted between 60 and 90 minutes, and took place in a school or university office. The exceptions were the interviews with Ritva and Jorma, the only participants I had met previously-their interviews took place in out-door Helsinki cafes. All of the participants spoke English fluently, and all of the interviews were audio-recorded. The rest of the article examines the data and concludes with some generalized findings.

\section{How Finnish Educators Think About Civil Society}

The data has been divided into seven subsections, all emanating from the responses to specific interview questions. The first four topics relate to the commons and issues of social class. They focus on equal opportunity, schooling and the commons, cooperation, and taxes. The next three subsections address the accommodation of the cultural Other, multicultural education, and the rise of a nationalist, anti-immigrant political party called the True Finns. ${ }^{3}$ This last section will include a discussion about teaching controversial issues in the Finnish classroom, especially as they pertain to threats to social cohesion. All of the sections will primarily rely on the words of the nine educators who participated in this study. For each of these sections, background information for the Finnish context will be interspersed with the words of the educators.

\section{The Thoughts of Finnish Educators on Equal Opportunity in Finland's Civil Society}

There are many definitions for the term civil society. In academic jargon the term often refers to various non-governmental organizations and institutions. Other definitions include the family and the private sphere, or the third sector of society after government and business. In this study, however, civil society simply refers to a community of citizens linked by common interests and collective activity. This definition of civil society allowed the data analysis to address the commons and social cohesion, especially around issues of class, culture, and immigration. It also gave space for a discussion of the rise of the far-right nationalist party in Finland called the Finns Party, formerly the True Finns.

A school does not work within a vacuum. The values that are deeply embedded in a society tend to be reflected in the school curriculum, both explicit and implicit. Sahlberg (2014) states, "Education policies are necessarily intertwined with other social policies, and with the overall political culture of a nation" (p. 39). Simola (2015) applies Sahlberg's general statement to Finland: 
[Finland's] welfare state is still seen as the legitimate representative of society and of the common good ... As a cornerstone of the continuity and consensus in Finnish educational policy, belief in education as an agent for social equality has remained stronger than in many other advanced liberal countries. (p. 73, emphasis added)

Bearing this in mind, it is prudent to begin the analysis with the Finnish educators' thoughts on the importance of the public school for equality in Finnish civil society.

Not surprisingly, all nine participants believed that the public school is of vital importance to civil society in Finland. Tuovi stated that the public school "is essential for cultural knowledge and our country's values to be passed on to the next generation." Hannu pointed out that the school performs a similar function as the military once did in that it "brings all the kids in Finland into the same room, which is important for civil society. People do not see themselves as 'us' versus 'them' but as 'we."' The concept of we speaks to the notion of equal opportunity that was mentioned unsolicited by eight of the nine participants. Dorotea emphasized that everyone should have equal access to education and healthcare, even "people with little money." Birgit stated this idea succinctly: "Equality is the Finnish way." A 1995 study conducted shortly after the government's brief flirtation with neoliberalism found that "Finnish parents felt strongly about equality and equity, and did not support the tenets of market-oriented schooling or the ideology of competition ... [T] hey were worried about the inequality of educational opportunities" (Simola, 2015, p. 211). Given the position of the parents, it is no surprise that the teacher-participants held a similar stance.

The oft-heard refrain about commitment to equal opportunity is likely a factor for the lack of public support for private schools in Finland. Although occasionally a segment of the public calls for private schools (Simola, 2015), the only ones that exist in Finland are based on different educational philosophies such as Waldorf. All but one of the participants opposed a private school system in Finland. The lone dissenter was Dorotea, who believed that academically gifted students are held back in the public system: "If some parents want a school for their kids who are great at maths and sciences, that's fine with me ... but too many private schools would create a problem." Ronja explained what this problem might be: "If the funding cuts [to public schools] continue, there will be private schools, and with more and more private schools class differences will become greater. This will break the equality aspect of Finnish education." For this reason, she preferred to see the public school system address the issue of improving pedagogy for exceptionally bright students rather than see the creation of a private school system.

Although the notion of equality was important to all nine participants, a couple of them seemed to be harbingers of gloom. Hannu stated this in blunt terms: "Here in Finland, we say everyone is equal, but we are only pretending because we are not all equal." Of course, this is true in a literal sense, but a good example about unequal access to good schooling was provided by Hannu's colleague, Jorma, at the University of Helsinki.

The equality thing is changing now, changing a lot. They have closed many small schools, rural schools, because it isn't cost-effective to have them anymore. They are counting Euros now.

It appears that people living in rural Finland are the first to experience a lack of equal access to schooling. The state of national finances is the main reason: "About 1,000 comprehensive 
schools have been shut down during the first decade of this century. Many of them were small rural schools" (Sahlberg, 2014, p. 129). Despite this obvious imbalance in terms of equal educational opportunities, there were no suggestions from the participants or in the literature that the closure of rural schools was leading to greater social class distinction. This could change in the coming years, however. In fact, recent studies have demonstrated that divisions created through neoliberal policies in Finland are beginning to appear (Bernelius \& Vaattovaara, 2016; Raiker \& Rautiainen, 2016; Reay, 2016).

Wealth inequality and distinct social classes seemed to be anathema to all of the participants. This was best explained by the special advisor to the OAJ president, Ritva:

Finnish people think that equality is the main key for a peaceful society. If a country does not have very poor people, which is the situation here, and everyone is given equal opportunities, it will be more peaceful.

One of Ritva's job responsibilities is to travel to other countries to discuss education issues. She has seen first-hand the abject poverty that exists even in extremely wealthy nations such as the United States. It is impossible to provide equal educational opportunities for an entire population if large segments are worried about paying for housing and food. A question arises about what role the participants saw for the school around supporting people and the Finnish commons.

\section{The Thoughts of Finnish Educators on Schooling and the Commons}

The economic and social welfare of Finnish society is based on an egalitarian public system of schooling. (Finnish Educational Evaluation Council, 1994, cited in Simola, 2015, p. 241)

There is little doubt that most Finnish people consider their country's social welfare state to be a vital component of the common good. Further, as the above quote suggests, most Finns contend that the school itself underpins the commons and civil society in Finland. In fact, almost all of the participants in this study were very overt about this. Nils claimed that "ideas like public healthcare and free university tuition are so obvious in Finnish society." Nils explained to me how he does this with students in his high school social science courses in the following discussion:

Nils: I ask the students, "What is important in our society?" They always answer, "Education and healthcare." I then ask, "How should we build up our education and healthcare systems? I tell them there are two quite different ways: The Nordic Way and the American Way. After explaining to them what these two ways look like, they always choose the Nordic Way.

Paul: Although many Canadians agree with the values in the Nordic Way, many others would not. For example, it is very difficult to get public support for free university tuition. This is likely because of our proximity to the US.

Nils: Yes, I can see that. It does cost money for these things. Our government is a huge owner of industry. We own over 20 billion Euros in stocks of electricity and oil companies, and in other industries, too. Many Americans would look at Finland and say that we have a communist government. But it's not communist. It's just the Nordic Way. 
Nils' description of the way he teaches to support the Nordic Way and the Finnish commons is steeped in political ideology. Yet when asked about teaching in support of the commons, Nils answered that he is not a political teacher:

Well, our schools have always been places where politics don't emerge. They're neutral places. As a teacher of social sciences, it's very important to me that the school remains neutral.

It is possible that Nils does his best to teach about the Nordic and American ways to fund healthcare and education in a neutral manner. Teachers, however, are not robots - their personal stance on important issues are likely discernable to alert students. The school cannot be a neutral site because everything about teaching is political (Apple, 2004; Orlowski, 2011). Teacher neutrality will be discussed later.

The political ideology of the Nordic Way resembles a social democratic model rather than a communist model (Orlowski, 2011). There are myriad private industries in Finland, including large mega-corporations like Nokia. There are also large state-owned industries such as Norway's oil company called Statoil. The Nordic Way includes using the taxes and royalties from these industries to pay for the commons. To many Americans and Canadians, this is not the way a society should function because individual entrepreneurs are not able to personally profit from these resources to the same extent. The current neoliberal paradigm that dominates both North American countries makes the Nordic Way seem even less viable to many Americans and Canadians (Orlowski, 2011, 2015).

At one point, Nils stated that supporting the commons is "so obvious in Finnish society because it has always worked for us." This could be why he considers his way of teaching about the commons to be a neutral endeavour. Tova, however, was concerned that this complacency could lead to problems:

I think the Finns do not perceive the importance of the commons, as we are so used to it. It has always been there for us. And now the government is decreasing the funding for some things, like the school system.

There is validity in Tova's concern about people becoming complacent about the social welfare state, and this has been borne out in the aforementioned Finnish studies (Bernelius \& Vaattovaara, 2016; Raiker \& Rautiainen, 2016; Reay, 2016). This same neoliberal dynamic has worked to weaken support for the public healthcare system in Saskatchewan, Canada, which happens to be the site of the first public healthcare system in North America (Orlowski, 2015). In one respect, however, Finnish educators foster a powerful value that is less common in Canada.

\section{Cooperation Versus Competition in Finnish Schools}

Perhaps one of the biggest differences in the schooling of Finnish and Canadian youth pertains to the philosophical tension between cooperation and competition. All nine participants stated unequivocally that fostering cooperation is hegemonic in Finnish schools. Both education professors claimed that cooperation is stressed in the teacher education program at the University of Helsinki. Hannu explained why:

Finnish teachers have themselves been taught to really emphasize cooperation in their teacher education program. So there is not much focus on competition in the schools at all. 
The focus on cooperation is because of our history-we have seen what a good public education system can do for most people, and for our country.

The six teacher-participants concurred with Hannu's assessment. All of them said that they almost always have stronger students help weaker students while working in small groups. In fact, two of the participants said that it is "illegal" for teachers to group the students according to ability. Nils explained why this works so well in Finnish classrooms:

Cooperation works well with Finnish people in general. This is because we are quiet people, and we act more or less the same, and we have become used to cooperating with each other. So cooperation is already accepted by the teachers and by the students.

The cultural homogeneity among the Finnish population that Nils points to could at least partially explain why cooperation is so readily accepted in their classrooms. Whatever the reason, it is clear that Finnish educators strongly emphasize cooperation with their students.

This is not to suggest, however, that competition is completely absent from a Finnish student's school experience. Dorotea says:

We teach the children not to compete with each other. We tell them to compete with themselves. "I say to them, "You should try to do better! If you don't like the result then you should try harder, think of different strategies, and ask for help." So we teach them not to compete with each other, but with themselves.

It is possible that the Finnish emphasis on cooperation, in tandem with trying to better oneself, is the underpinning of their egalitarian ethos and strong support for the commons. This is significantly different from the heavy emphasis on competition in Canadian and especially American schools. Perhaps the greatest indication of this can be seen in their attitude toward paying taxes.

\section{The Finnish Attitude Toward Taxes and Civil Society}

Finland, as with the other Nordic nations, has a reputation as a country with high taxes. Yet, all of the Finnish educators in the study spoke in positive terms about paying taxes in order to strengthen civil society. Although most Canadian participating teachers in my research have spoken favourably of what taxes can do for society, the Finns spoke with much more overt enthusiasm, even passion. For example, Grade 4 teacher Ronja said:

We know what we get from paying our taxes. It's just something we grow up knowing, so we never question it. Like free university tuition. I only recently finished my five years of university, and I have no student debt whatsoever from being a student for so long. It doesn't matter which income level your family has, you can study at university here in Finland.

Many recent graduates from Canadian universities would welcome taxes being used for free tuition, given the constant refrain about overwhelming student debt in the public discourse over the past few decades in Canada.

A progressive taxation scheme is a society's best strategy to redistribute wealth among its population and lessen the gap between the affluent and the economically marginalized. Research has proven that everyone benefits when wealth inequality is less pronounced (Wilkinson \& 
Pickett, 2010). Bearing this in mind, the Finns show a mature attitude toward paying taxes, as demonstrated by the following excerpts:

Hannu: A clear majority of Finnish citizens would like to pay even more taxes because we see the benefits that come from taxes. We know it has helped us get good schooling, healthcare, and all those things that are part of the social welfare state ... The Finnish people trust that their taxes will be used for good. I know of no other nation that has this level of trust that their taxes will be used for good.

Ritva: The main newspaper here in Helsinki recently had a story that discussed a survey that showed the Finnish people are fine with paying taxes. If the taxes are used for things like education and healthcare, we are happy taxpayers.

The concept of "happy taxpayers" may be unique to the Finns, or perhaps unique to many citizens in the other Nordic countries. It is definitely not common to think of Canadians and Americans in this way. All nine participants expressed satisfaction with the ways in which their taxes are used to support the social welfare state.

A nation's economy, however, is always in a state of flux. Two participants expressed caution about always expecting taxes to enhance the Finnish way of life:

Nils: Recently, the [Finnish] economy is going downward. The media is now asking the question: Do we have a society that we can't afford anymore? I also ask the students to discuss this question.

Tova: This is just my opinion, but I think my generation is more happy with paying taxes than younger people, younger Finns, are today.

Public support for Finland's high tax rates is the main reason the nation has such a strong social welfare state. For the most part, the citizens seem pleased with this socioeconomic arrangement. The words of Tova and Nils, however, hint that there may be changes in the not too distant future around taxation and the Finnish commons. Once again, other recent studies suggest that this is true (Bernelius \& Vaattovaara, 2016; Raiker \& Rautiainen, 2016; Reay, 2016).

This is not the only issue that the Finnish people must soon contend with. Global issues such as refugees and immigration in general are forcing the Finns to ask themselves difficult questions about the future of their country. The next three sections suggest that these questions will be asked of Finnish educators in the very near future.

\section{Accommodating the Cultural "Other" in Finland}

Due to the very small numbers of minority groups, it is still possible to speak about a relatively homogenous national culture in Finland. (Simola, 2015, p. 175)

The preceding four subsections indicate that when it comes to the commons, the Finnish participants believe in the Nordic Way and its commitment to equal opportunity in education and equal access to healthcare. This is an extremely important component for social cohesion and for a strong civil society. There are signs that this commitment to equality may be waning, but for the main, this study suggests that it is much stronger among Finnish educators than what was found in my previous research among Canadian teachers (Orlowski, 2011, 2017). Another vitally 
important aspect of social cohesion is the ways in which a society treats its new immigrants. The next three sections address this in the Finnish context.

\section{Finnish Teachers Speak About Immigrants, Refugees, and Indigenous Peoples}

Finland has three official languages: Finnish, Swedish, and Sami, the language of the Indigenous peoples of the Nordic countries. In terms of ethnic demographics, the country's population of 5.5 million is composed of 93 percent Finnish, 6 percent Swedish, 0.5 percent Russian, and 0.5 percent of tiny minorities of Estonian, Sami, Romani, Somali, and various other Middle Eastern and African peoples (Index Mundi, 2017). Finland has the least cultural diversity of any European nation, the result of many decades of a very strict immigration policy (Sahlberg, 2014).

Immigrants comprise less than 1 percent of Finland's population, almost all of them living in and around Helsinki. The participants were aware of the growing presence of the cultural Other. Several said they overhear students make derogatory comments about the Russians. Two suggested that the reason for this was that Finland has had a long, complex, and often unpleasant history with its powerful eastern neighbour, and that anti-Russian sentiments likely emanate from the students' homes. It seemed, however, that another immigrant group was having a much more difficult time in Finland.

By 2011, there were approximately 13,000 Somali people living in Finland, mostly in or near Helsinki (Sahlberg, 2014). Dorotea answered my question about accommodating immigrants with a clear description of the dilemma faced by both the Somali immigrants and by the Finnish authorities:

In general, we are very bad at helping them. But then again, some Somalis do not try to learn the Finnish language. Somali women, for instance, stay at home with the kids. They engage with other Somalis, not with the Finns. But I am not saying the Finnish people are good at trying to engage with them either. We tend to think of them as Somalis, not Finns, and that they are quite different from us ... I personally think we should take many more refugees than we do, especially with the catastrophic situations many of them are living with. But on the other hand, if we do take more, how will it go? We don't treat them well. We don't teach them Finnish. We don't employ them. And then people complain that they are living on social welfare.

The OECD study from a decade earlier warned of the need for government to implement policy designed to help immigrants (Grubb et al., 2005). Another study from that same period (Degni, Pöntinen, \& Mölsä, 2006) described challenges facing Somali immigrants living in Finland that Dorotea describes are still in place.

Dorotea described a dynamic that is also prevalent in the major cities in Canada. The dominant group often frames the issue of assimilation as unwillingness on the part of the newcomer rather than an inability or lack of opportunity to do so. Birgit explained how she dealt with living in the United Arab Emirates (UAE) for four years:

I think that you just have to adapt to where it is you are living. That's my philosophy. I try to adapt to fit in with the people in the country where I am living ... Not all immigrants in Finland share this philosophy. 
Birgit's two children went to an international school in the UAE. Of course, immigrants and refugees living in Finland are not afforded the same educational experience for their children. She understood this, but still seemed to imply that more effort could be made on the part of immigrants to assimilate into Finnish society.

Two participants also suggested it would be helpful if immigrant groups such as the Somalis were separated so that they were not living in large numbers in the same proximity. Ritva suggested this would help encourage them to interact more with the Finnish people. Tuovi, a female veteran teacher nearing retirement, had a different reason for wanting the Somalis to be dispersed.

I don't want so many living in the same building. There are lots of Somalis living in the same building where I am living now. I am uncomfortable sometimes, like when I go to the laundry room and everyone else in there is Somali.

Tuovi is speaking as a woman nearing her senior years rather than as a teacher. Finland's recent influx of immigrants that look vastly different from the typical Finn is a new phenomena, and an argument could be made that Tuovi's discomfort is understandable, perhaps a result of xenophobia but not necessarily racism.

A visitor to Helsinki would likely notice the Roma people who often are busking on the streets as a way of obtaining money. Two of the participants commented that the Roma are linked to crime in some way. The following two participants were more sympathetic, however, and implicated the Finnish attitude as part of the problem:

Dorotea: The Roma people come from somewhere in Asia, and their history is really complicated. They've always been looked at in a bad way. Of course, some of their traditions aren't compatible with the societies of the West, but most of them are decent people. It's sad that when a few of them do bad things, then we tend to look at them like they are all bad. But we don't know enough about them. And it's also the same with the Sami people.

Hannu: We have not done anywhere near enough to help the Sami or the Roma people. This is likely because of the homogeneity factor you mentioned. Finnish people like to think that they have developed equal opportunity for all, but the fact is they have not done this ... Most Finnish people are not interested in learning about other cultures.

These excerpts imply that the Finns have not made accommodating the cultural Other a priority-it is difficult for non-White peoples to live comfortably in mainstream society. In fact, the 2005 OECD study highlighted a growing tension in Finland because of its Roma population (Grubb et al., 2005). Dorotea and Hannu suggest part of the problem lies with the lack of interest the Finnish people demonstrate in learning about people from other cultures, whether Indigenous or from afar. Although immigrant and refugee groups in Canada do not have it very easy, one gets the sense that it is not as difficult for them to make their way. That is not the case for Indigenous peoples in Canada (Cottrell \& Orlowski, 2013).

The previous sections that focused on the importance of the commons and equal opportunity do not appear to be relevant to people such as the Sami, the Roma, and the Somalis. When it comes to the cultural Other, there appears to be a crack in the social cohesion of Finnish 
society. The next section explores what it is the schools are doing to help ameliorate this situation.

\section{Schooling and the Cultural Other}

[Immigrant] pupils could be characterized as invisible: no one speaks about them with ease, no one seems to know what to do with them, and no one makes any positive references to their existence in the Finnish school system. (Simola, Rinne, \& Kivirauma, 2015, p. 37)

Finland's lack of cultural diversity is likely a large reason why a recent study by three Finnish researchers yielded the bleak conclusion stated above. Although the teacher-participants in my study did not speak of recent immigrants to Finland in the same disheartening manner as what Simola et al. (2015) found, there were some similarities. For example, the participants pointed to a lack of a clear strategy over what needs to be done to help these people succeed in Finnish society. In Canada, by comparison, some teachers attempt liberal, pluralist, or critical forms of multicultural education (Orlowski, 2011).

A frequently heard comment among the participants was that the language barrier was the main reason for why immigrants had difficulty assimilating into Finnish society. Although several mentioned that language courses were offered to the immigrant students, a few countered that there are not nearly enough spaces to meet the demand. When I asked whether teachers attempted to make the curriculum more culturally relevant for students from other cultures, no one acknowledged knowing any teachers who did this.

Ronja stated a goal of Finnish schools to help alleviate the tensions caused by changing demographics.

Every school in Finland is working to help raise tolerant children. Some children are brought up in homes that are not tolerant. We try to gently, subtly, make them more tolerant. But we're not aggressive about it, because we do not want to upset the parents. We try to give them both sides, make them question what they hear from other places, like their homes, make them think about it. Then they can make up their own minds. We give them the tools to look at the situation.

Ronja did not describe how she or other teachers encourage tolerance toward the Other. Teaching for tolerance is better than not doing so, but Ronja's comments indicated major differences in how Finnish teachers address cultural tensions in society compared to Canadian teachers. The regressive views of some parents, for example, are not a deterrent for teachers concerned with racial or cultural tensions. Teachers I have worked with are not all that concerned if they upset parents who hold negative views about immigrants or people from other races and cultures. Further, state-sanctioned formal curricula encourages acceptance rather than tolerance of the so called Other. ${ }^{4}$

Hannu, an education professor, spoke of a research project he was part of called Transit.

My grad students interviewed 50 ninth grade Somali students, their last year of comprehensive education. Every single one of them said they loved school here in Helsinki. They loved it, all of them loved school! But no one knows what happened to 
them. It is like a black hole. They simply stop going to school. We have not studied this group after the ninth grade to understand why.

Ritva, the special advisor to the president of the teachers' union, also spoke of the mystery of why Somali students are not graduating from high schools in Finland. Indigenous students across Canada and Black students in Toronto graduate at about half the rate of their White peers (Cottrell \& Orlowski, 2013; Orlowski, 2011). This speaks to problems with the institution of the school itself. It seemed like the situation for non-White students in Finnish schools is even more dire. Since 2011, all preservice teachers in Canadian teacher education programs are required to take a course in Indigenous Studies and a course in anti-oppression education (Cottrell \& Orlowski, 2013).

Ritva spoke of two initiatives Finnish authorities have recently implemented in an attempt to improve the educational outcomes of immigrant students. One was to increase the pay of teachers if they work in schools with significant numbers of immigrant students. The other initiative was to give every immigrant student a new iPad to help with their school experience. She used the term "positive discrimination" to describe this strategy. Unfortunately, this has created a negative reaction in certain segments of the Finnish population. Using tax dollars to help immigrant groups is part of the anger that is fuelling a major threat the Finnish consensus around civil society, the appearance of a political movement known as the True Finns.

\section{Teaching and the Anti-Immigration Movement of the True Finns}

Finland is a good example of how nothing is stable ... If you look at Finland compared to other countries, we are doing well in education and gender equality. But if you look from a Finnish perspective, comparing the situation to what was previously, it's worrying. The whole idea of the welfare state is under attack politically from the Right. (Li Andersson, Left Alliance leader, cited in Burtenshaw, 2017, p. 2)

In 1995 a populist, nationalist political party called the True Finns arose from the ashes of the Finnish Rural Party, which in 2015 changed its name to the Finns Party. Although there is some disagreement around economic policy-some members do not support the Finnish social welfare state while others do support it but for ethnic Finns only-all members adhere to values of social conservatism, socio-cultural authoritarianism, and ethnic nationalism. Since 2015, the True Finns are part of Finland's governing conservative coalition. The movement is decidedly anti-immigrant, and poses a serious threat to social cohesion in Finland. The popular political leader of the Left Alliance, Li Andersson, explains what the recent appearance of the True Finns in the Finnish government has meant to Finnish social cohesion: "Unfortunately, they have caused a lot of damage. They have succeeded in polarizing Finnish society. Their anti-immigrant rhetoric has managed to turn widespread insecurity about the economy against immigrants (cited in Burtenshaw, 2017, p. 6). Clearly, this is a major threat to the entire theme of equality that has been so prominent throughout the past several decades of Finnish social policy.

All of the participants in the study viewed the rise of the True Finns with concern. Many agreed with the analysis of Li Andersson and offered economic reasons for the popularity of the anti-immigrant movement. The following are examples:

Jorma: We have more and more people who are unemployed because they are closing factories in some parts of Finland. Some are about my age [late 40s], but they have little 
education, so they do not have many options, and they turn to the True Finns. This is causing more polarization in Finland.

Tova: The people that voted for the True Finns are mostly working class. They are worried about their future.

Nils: The True Finns are for real because they hold the balance of power now. They have never held power before. Like in most European countries, the True Finns offer easy solutions to many complex problems. That connects them to people who are worried about jobs, and worried about immigrants.

The economic line of reasoning for the rise of this nationalist movement sounds eerily similar to the rise to the White House of Donald Trump in the US. These interviews took place before Trump's candidacy was formalized, but it would appear that the dynamics in Finland overlap with the American situation, namely, White working-class fears over the loss of jobs, and the loss of traditional national identity. As in the US, immigrants are most vulnerable under these conditions.

During his interview, the sociologist of education at the University of Helsinki, Hannu, offered a different explanation for the True Finns phenomena:

The True Finns are not the first movement of authoritarian nationalism in Finland. We had a civil war following World War I that is not discussed in the schools. The Red side and the White side fought each other, there were concentration camps in East Karelia and other places, and Finns were killing Finns. This needs to be taught in our schools, not ignored. We should teach what the Finns did to other Finns. And now the True Finns are back. Schools should teach about this, teach the real history of Finland!

This period of Finnish history pitted groups aligned with fascism against groups aligned with socialism. Hannu further explained that the original True Finns originated during this time, and because Finns are not taught about this, the nationalist inclination has been allowed to fester and reappear.

It is unlikely, however, that Finland's teachers will address these uncomfortable episodes in the country's past and present, at least in a critical manner. It was striking that all six teacherparticipants stated unequivocally that it is a teacher's job "to remain neutral, not to indoctrinate the students," as one put it. Whether I suggested teaching about racism, the True Finns, or the new nuclear power plant the Russians were building in northern Finland, the need to remain neutral was always the response. Jorma, the teacher educator at the University of Helsinki offered a partial explanation for this common answer:

Teacher education here is pretty apolitical. It's a hidden agenda that suggests [that] if you are a teacher, you are not supposed to express political views.

If the preservice teachers are not encouraged to take a stance on controversial issues or even to teach about them, it is unlikely that they will do so once they begin their teaching careers. Further, this apolitical style of teaching may not be very difficult for Finnish teachers to accept as research demonstrates that "their political opinions are rather conservative" (Simola, 2015, p. 212). Both Hannu and Ritva, however, opposed teachers using omission as a hegemonic strategy, especially as it pertains to fascism in Finland's history and the rise of the True Finns today. For 
them, the anti-immigration stance of the True Finns poses a grave danger to social cohesion in Finland.

\section{A Canadian Educator's Reflections on the Role of Finnish Teachers for Social Cohesion}

A few clear similarities that the Finnish participants share with Canadian teachers who have participated in my studies is a passion for teaching, thoughtful reflections to posed questions, and a desire to help students. Indeed, educators in both countries express a desire to help strengthen civil society. This study's main focus was to explore the role of the Finnish teacher in support of the commons, in strengthening civil society, and in fostering social cohesion. An objective was to listen to these educators describe their perspectives on the particular model of social democracy called the Nordic Way, an approach to doing politics that has been more effective in withstanding neoliberal forces than in Canada (Orlowski, 2016).

It is a simple fact of politics in capitalist democracies that private interests shape, and often decide, public policies. Yet, the Finns have demonstrated that a collective consciousness in which equality, equal opportunity, and a strong commons are cherished can regulate capitalist impulses that tend to place profits about the common good. The nine participants were unanimous in their support of the commons and Finland's generous social welfare state. This support seemed to be in the air that they breathe. Ritva Semi's comment that "equality is the main key for a peaceful society" spoke volumes as to why "equality is the Finnish way," as Birgit put it. The Finns are "happy taxpayers" because they can see the benefits they receive from the economics inherent in the Nordic Way. Only a minority of Canadian teachers, indeed, a minority of Canadian citizens, are happy to pay taxes (Orlowski, 2015). The emphasis Finnish teachers place upon cooperation rather than competition is also a major difference between schools in Finland and Canada.

In The Finnish Education Mystery, Simola (2015) claims that geopolitics has influenced the Finnish people differently than people in other parts of the world, including their Nordic neighbours:

Finnish culture still incorporates a meaningful element of the authoritarian, obedient and collectivist mentality, with its pros and cons. Due to its geographical and geopolitical location, Finland has always been a border country between the East and West. (Simola, 2015, p. 209)

One of the positives Simola (2015) alludes to is the Finnish consensus around a strong commons, undoubtedly a result of the collectivist mentality he speaks of. It is the unique geopolitics of Finland that demonstrates the limits of comparative education. Finland has had a complex relationship with Russia, its (formerly communist) neighbour to the east. Canada has had a complex relationship with the United States, its powerful neighbour to the south that wholeheartedly supports neoliberalism. The political and economic forces these two world powers have foisted upon other parts of the world inevitably influence economic policy in other nations.

Simola (2015) points to the authoritarian impulse in Finnish society, however, a trait that may pose problems for certain segments of the Finnish population. Immigrants and refugees, especially those who look quite different from the Finns, appear to be vulnerable to discrimination and exclusion from mainstream Finnish society. The six teachers in the study 
seemed to be somewhat flummoxed around how best to handle these social relations. The Finnish consensus looks to be threatened because of the authoritarian and nationalist reaction that is manifested in the burgeoning True Finns movement represented in the Finnish government as the Finns Party.

A major difference in the Finnish and Canadian school systems appears to be in how the teachers reconcile social tensions caused by different cultures living side-by-side and amongst each other. Canada, of course, is a nation primarily composed of immigrants. Canadians have experienced multiculturalism far longer and more intensely than the Finns have. This is demonstrated in the focus on anti-oppression education and the accepted practice of fighting racism in Canadian society. If it is thought that a student's racist attitudes emanate from the home, most Canadian teachers see it as their duty to address this (Orlowski, 2011, 2017). There is still a long way to go in combatting racism in Canada, especially toward Indigenous peoples. Provincial Ministries of Education across Canada claim to be committed to this.

The Finnish teacher-participants in this study, however, were committed to attempting neutrality in their teaching of these social problems, or perhaps even ignoring them altogether. Considering the constant movement of large groups of people today, these are untenable responses. "The most interesting question for the future might well concern how Finnish schools and their teachers face the inevitable changes and challenges coming from the globalizing world" (Simola, 2015, p. 175).

The place to start is with teacher education programs. The stakes are high as Finnish social cohesion appears to be threatened by the growing popularity of the True Finns. In this respect, Finnish educators can learn from Canadians. On issues such as promoting cooperation and a strong commons, Canadians can learn from the Finns. It appears, however, that neoliberalism's influence to weaken the commons and eschew equal opportunity is gaining traction in Finland.

The research question for the study was, "How do Finnish educators think about the school's role in supporting the commons and in fostering social cohesion with immigration?" Despite the small sample set of Finnish participants, I believe it represents a cross section of views of educators in contemporary Finland. This is borne out with recent studies mentioned in the literature review. Civil society in Finland is evolving as it is here in Canada. There are differences to be sure, but educators in both countries may glean some insights into what is taking place in the other country. For Canadians, this could mean promoting the commons through pedagogy around progressive taxation and cooperation. For Finns, using anti-racist pedagogy to take on regressive views about immigration in the home would strengthen civil society. Both insights challenge neoliberal and right wing social views, and are therefore worthy of consideration and perhaps implementation in educational policy.

\footnotetext{
Endnotes:

${ }^{1}$ In the twenty-first century, PISA has become the preferred guiding instrument for many national governments in the design and implementation of policy changes.

${ }^{2}$ I had recruited a tenth participant, a high school teacher who lived in the city of Oulu in northern Finland, but shortly before the scheduled interview she informed me that she was unable to participate.

${ }^{3}$ In 2015 the party changed its name to the Finns Party, but in the interviews the participants referred to it as the True Finns, a name I use throughout this article.
} 


\footnotetext{
${ }^{4}$ As an example of a state sanctioned curriculum designed to be as inclusive as possible, see the Social Justice 12 curriculum in British Columbia: https://curriculum.gov.bc.ca/sites/curriculum.gov.bc.ca/files/pdf/10-12/socialstudies/en_ss_12_scj_elab.pdf
} 


\section{References}

Andere, E. (2015). Are teachers crucial for academic achievement? Finland educational success in a comparative perspective. Education Policy Analysis Archives, 23(39). http://dx.doi.org/10.14507/epaa.v23.1752

Apple, M. (2004). Ideology and curriculum, (3rd ed.). New York, NY: Routledge-Falmer.

Bernelius, V., \& Vaattovaara, M. (2016). Choice and segregation in the 'most egalitarian' schools: Cumulative decline in urban schools and neighbourhoods of Helsinki, Finland. Urban Studies, 53(15), 3155-3171. https://doi.org/10.1177/0042098015621441

Burtenshaw, R. (2017, December). Where next for Finland's welfare state? An interview with Li Andersson. Jacobin Magazine. Retrieved from https://www.jacobinmag.com/2017/12/liandersson-left-alliance-true-finns

Cottrell, M., \& Orlowski, P. (2013). Racialized poverty and the promise of schooling: Searching for equitable educational outcomes for Aboriginal peoples in Saskatchewan, Canada. In E. Brown \& P. Gorski (Eds.), Poverty \& social class (Vol. 6). Newcastle, UK: University of Newcastle Press.

Degni, F., Pöntinen, S., \& Mölsä, M. (2006). Somali parents' experiences of bringing up children in Finland: Exploring social-cultural change within migrant households. Forum: Qualitative Social Research, 7(3). http://dx.doi.org/10.17169/fqs-7.3.139

Grubb, N., Jahr, H., Neumülle, J., \& Field, S. (2005). Equity in Education: Thematic Review Finland. OECD. Retrieved from http://www.oecd.org/education/school/36376641.pdf

Hargreaves, A., \& Shirley, D. (2011). Beyond standardization: Powerful new principles for improvement. In A. Ornstein, E. Pajak, \& S. Ornstein (Eds.), Contemporary issues in curriculum (5th ed., pp. 318-327). Toronto, ON: Pearson.

Index Mundi. (2017). Finland demographics profile 2017. Retrieved from http://www.indexmundi.com/finland/demographics_profile.html

Orlowski, P. (2011). Teaching about hegemony: Race, class \& democracy in the 21 st century. New York, NY: Springer.

Orlowski, P. (2015). Neoliberalism, its effects on Saskatchewan, and a teacher educator's response. Alternate Routes: A Journal of Critical Social Research, 26(1), 223-250.

Orlowski, P. (2016). Saskatchewan teachers and a study abroad experience in Finland: "I love how the Finns respect their teachers!" Journal of Educational Administration \& Foundations, 25(3), 17-37.

Orlowski, P. (2017). The light to the left: Conceptions of social justice among Christian social studies teachers. in education, 23(1), 66-91. 
Partanen, A. (2016). The Nordic theory of everything: In search of a better life. Toronto, ON: HarperCollins Canada.

Raiker, A., \& Rautiainen, M. (Eds.). (2016). Educating for democracy in England and Finland: Principles and culture. Abingdon, UK: Routledge.

Reay, D. (2016). How possible is socially just education under neo-liberal capitalism? Struggling against the tide? Forum, 58(3).http://dx.doi.org/10.15730/forum.2016.58.3.325

Sahlberg, P. (2006). Education reform for raising economic competitiveness. Journal of Educational Change, 7(4), 259-287. http://dx.doi.org/10.1007/s10833-005-4884-6

Sahlberg, P. (2014). Finnish lessons 2.0: What can the world learn from educational change in Finland? (2nd ed.). New York, NY: Teachers College Press.

Simola, H. (2005). The Finnish miracle of Pisa: Historical and sociological remarks on teaching and teacher education. Comparative Education, 41(4), 455-470. http://dx.doi.org/10.1080/03050060500317810

Simola, H. (2015). The Finnish education mystery: Historical and sociological essays on schooling in Finland. New York, NY: Routledge.

Simola, H., Carlgren, I., Klette, K., Myrdal, S., \& Schnack, K. (2015). "Changes in Nordic teaching practices: From individualized teaching to the teaching of individuals." In $\mathrm{H}$. Simola (Ed.), The Finnish education mystery: Historical and sociological essays on schooling in Finland (pp. 178- 203). New York, NY: Routledge.

Simola, H., Rinne, R., \& Kivirauma, J. (2015a). "Constructing a new system of reason in Finnish schooling." In H. Simola (Ed.), The Finnish education mystery: Historical and sociological essays on schooling in Finland (pp. 27-47). New York, NY: Routledge.

Simola, H., Varjo, J., \& Rinne, R. (2015b). “Against the flow: Path dependence, convergence and contingency in understanding the Finnish QAE model." In H. Simola (Ed.), The Finnish education mystery: Historical and sociological essays on schooling in Finland (pp. 224- 251). New York, NY: Routledge.

Wilkinson, R., \& Pickett, K. (2010). The spirit level: Why equality is better for everyone. London, UK: Penguin Books. 